This is the revised version according to the erratum on October, 2021 http://www.e-iji.net/dosyalar/iji_2021_4_erratum.pdf

\title{
Do the Learner-centered Approaches Increase Academic Performance? Effect of the Layered Curriculum on Students' Academic Achievement in English Lesson ${ }^{1}$
}

\section{Burhan Üzüm}

Lecturer, Corresponding author, Department of Foreign Languages and Cultures, Siirt University, Turkey, uzum_b@siirt.edu.tr

\section{Ata Pesen}

Asst. Prof., Faculty of Education, Siirt University, Turkey, atapesen@siirt.edu.tr

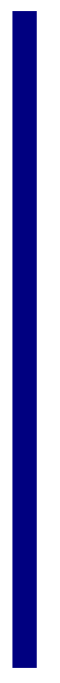

This study was conducted to demonstrate the effect of the layered curriculum on the academic achievement of the 9th grade students in English lesson. Based on quantitative research method, pretest-posttest matched with control group pattern, one of the quasi-experimental designs, was used in the study. The study group consisted of 67 ninth grade students stdying at Atatürk Anatolian High School, in the city center of Siirt, during 2016-2017 academic year. The applications to be conducted within the scope of the layered curriculum were prepared according to the unit- Seven Wonders. After the unit, in which the activities of the layered currciulum were going to be carried out was determined, an academic achievement test based on the learning outcomes of the unit was formed. After carrying out the reliability and validity procedures, the academic achievement test was conducted to the experimental and control groups as pretest and posttest. Following the pretest, the students in the experimental group did the activities having been prepared according to the layered curriculum for 6 weeks. The students in the control group, on the other hand, did the activities in their textbooks. At the end of the experimental process, both the experimental and the control group were required to take the academic achievement test as posttest.

Keywords: layered curriculum, academic achievement, English, learner-centered approach, English lesson

\footnotetext{
${ }^{1}$ This study was adapted from the master thesis of the corresponding author "The Effect of the Layered Curriculum on the $9^{\text {th }}$ Grade Students' Learning Style and Academic Achievement in English Lesson"

Citation: Üzüm, B., \& Pesen, A. (2019). Do the Learner-centered Approaches Increase Academic Performance? Effect of the Layered Curriculum on Students' Academic Achievement in English Lesson. International Journal of Instruction, 12(1), 1585-1608. https://doi.org/10.29333/iji.2019.121101a
} 


\section{INTRODUCTION}

Keeping in mind that over 500 million people speak Englih over the world (http://www.okunur.net/dunyada-konusulan-diller), it is indisputably true that English is the language of the "modern world" (Graddol, 1997 as cited in Salman, 2011, p. 1). Being aware of this reality, Turkey has made a series of changes in its language teaching policy throughout the time. For example, with the initiation of 8 -year compulsory education in 1997-1998, the foreign language was to be taught from fourth grade in primary schools. Afterwards, beginning from 2013-2014 academic year, foreign language teaching started at second grade in primary schools. Also, a-20-question foreign language test was added to the high school entrance exam in 2013 (Ozkan et al, 2016, p. 251). Moreover, fifth grade of the secondary schools is planned to be prepatory year for students and only foreign language and Turkish courses to be taught in 20172018 academic year (www.mymemur.com). Despite all these changes, the foreign language level of the students is not at the desired level (Paker, 2012 as cited in Cibisoglu, 2016, p. 2). According to EF English Proficiency Index (EPI) 2018, Turkey ranks 73rd country out of 88 countries based on English language skills.

It is necessary to arrange the learning environment effectively and efficiently in order to meet the individuals' demand for learning a foreign language. Brain structure of each individual differs and thus for a fruitful class environment, it is crucial to diversify teaching strategies (Ratey, 2001 and Shepherd, 1998, as cited in Nunley, 2003a, p. 26). As each student is at a differrent level and learns in different ways, their success levels can also change (Kingpore, 2004, as cited in Noe, 2008, p.6). As a result, when giving assignments and activities, providing students with opportunities to select from given activities makes the learning environment student-centered (Nunley, 2003b, p. 32).

In the light of the information given above, it can be said that there is a need for new approach and techniques in foreign language learning which are applied abroad and have furitful outcomes. Layered curriculum is said to be one of the learner-centered approaches which pays attention to indiviaul differences, learning styles, accountability and so on.

\section{Conceptual Framework and Review of the Literature}

According to Nunley (2003a), the main goal of the layered curriculum is to draw student's attention and interest, promote more complex and higher level of thinking, and increase student's responsibility. Thus, to prepare a lesson plan complying with the principles of the layered curriculum (See Figure 1), the unit that includes basic concepts, skills and tasks is divided into three layers. There are various activities that students can select and are suitable for different learning styles and skills in each layer. 


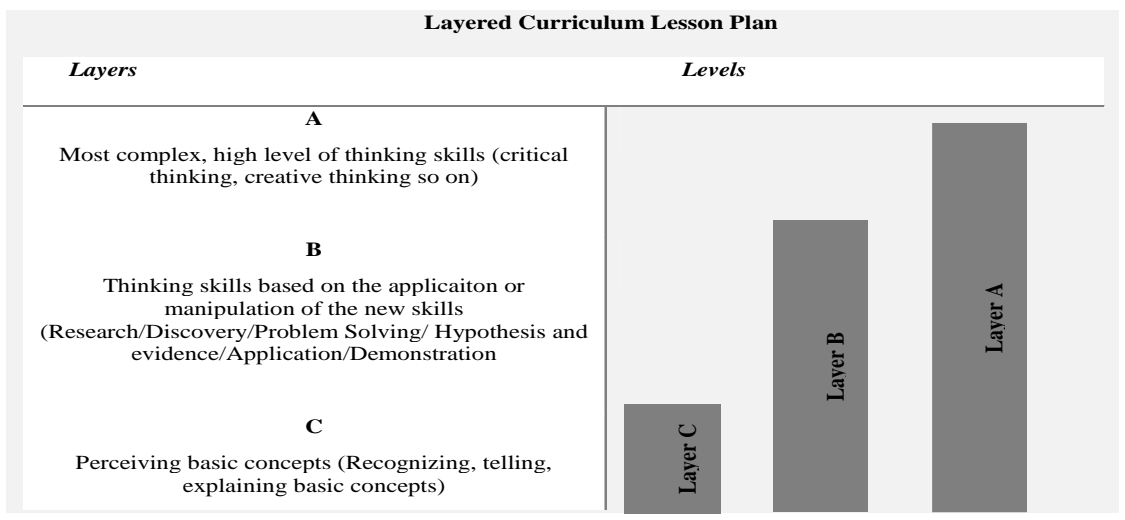

Figure 1

Layered Curriculum Lesson Plan (Nunley, 2003a)

Based on the hypothesis that students have different learning styles, layered curriculum is an approach which considers multiple intelligence, gives students the chance to link what they learn with the real world and focuses on diversifying learning environment (Koc, 2013, p. 65).

Demirel et al. (2006) demonstrate the layers within the scope of the layered curriculum as follows:

\section{Layer}

The tasks presented in this layer contains key concepts and comprehension skills that allow students to gain a general understanding of the topic. The maximum amount of activities is provided in this layer. The time and score required for each task differ because the tasks and activities given differ in difficulty. Students are free in choosing as many activities as they want in this layer, which should be between 65-70 points. Students are expected to perform all the activities they have selected in order to be able to pass to the next layer, B layer.

\section{B Layer}

This layer requires students to implement key concepts and skills they have attained in the previous layer. In this layer such activities in which students can use more complex and advanced thinking skills are presented. They need to implement and make discoveries, develop hypotheses and find solutions to the problems. Students are provided with fewer activity options in this layer, and according to their interests and skills, they choose an activity worth of 15 point.

\section{A Layer}

Of the layers within the scope of the layered curriculum, this is the layer that requires the use of the most complex and top-level thinking skills. Students are required to make inquiries, analysis and synthesis. They need to create an original product, develop a model, and put forward a new and unique idea. The students select a task worth of 15 points in this layer. 


\section{A Sample Layered Curriculum Activity List by Layers}

In his book chapter, Basbay (2015, pp. 261-263) introduces sample actitivity types for each layer that can be used as a reference while preparing layered curriculum activity lists as follows:

\section{Layer Tasks}

The maximum amount of activities are in this layer. The activities in this layer are rather easier compared to the activities in B and A layers, and the key concepts and operations are expected to be fulfilled.

1. Textbooks: Reading chapters and summaries, answering end-of chapter questions

2. News Articles: Summarizing new articles orally or in writing. Reading news articles related to the subject and uncovering important points. Summarizing news articles related to the subject in the class in a minute

3. Videos: Watching video records and taking notes. Watching records and anwering related questions. Watching video records and writing short summaries.

4. Computer Programs: Studying with computer program and noting down key concepts. After studying with the computer program, filling the worksheets. Answering the end-of program

5. Poem Selection: Selecting a suitable piece of poem related to the subject and reading it aloud

6. Listening to the Instructor: Listening to the teacher and taking necessary notes, and making summaries

7. Litening to the Tapes: Listening to the tape plaer or $\mathrm{CD}$ player and taking notes. Listening to the records and answering the related questions

8. Listening to the Speaker: Listening to the speaker and recording the lecture notes. Asking questios to the speaker. Presenting lecture notes by summarizing them in the class

9. Examining Models: Examining models and specimens.

\section{B Layer Tasks}

The students are expected to put their theoretical knowledge into practice in this layer. The students who successfully complete $C$ layer need to practise through comments.

1. Textbooks: Reading chapters and making commentary summaries, Reading endof chapter questions and adding new questions.

2. Writing: Writing a news paper article related to the subject. Writing a news bulletin, article or a review essay

3. Poem Selection: Composing a piece of poem related to the subject. Writing a lyric suitable for the compostion

4. Design: Designing a poster, brochure, identification card, identity document related to the subject, reading the chapter end questions and adding new questions

5. Laboratory: Experiments, simulations 
6. Research: Screening of information from different sources related to the subject and preparation of a report, examination and review of research reports and comparative summarization

7. Interview: Making an interview with a person, institution or organization related to the subject

\section{A Layer Tasks}

The number of the tasks in this layer is less than those in the $\mathrm{C}$ and B layers, however, higher than them in level. In this layer, students are expected to make analysis, derive new interferences, criticize and make original products.

1. Book Review: Reviewing a book and preparing a detailed review report, reviewing two books and analyzing the books within the specified criteria

2. Writing: Writing an original story, article. Explaining the impressions remaining from the study. Writing a self-criticism article.

3. Model: Designing an original model, designing maps, diagrams, posters, brochures.

How to Layer the Lesson?

Nunley (2016) describes how to layer a lesson in six steps as follows:

1. Povide options for assignments: Offer as many and various activitiy options as possible to allow nonreaders or low reading ability students to experience the feeling of success and let students to choose whichever assignments they wish. The sheets of the layered curriculum assignments can include lectuires, video, computer programs, workbook, poster, modeling, poetry, book reviews and so on. Variety means guiding the class rather than managing.

2. Require Oral Defense for Assignments: In order to discover whether your students have learnt or not, have brief face to face conversation with each of your student on the assignment they choose, as an addition or replacement for written exams. Face to face conversation is more valid than many other written exams. Oral defenses enable you to individualize your expectations to address various skills in the class. As a result, you can make different assessments for individual growth rather than determining a general criteria for all students.

3. Present Your Lectures As An Option (Even Record Them): Students' attention is at the highest point only when they willingly perceive the lectures given by the teacher rather than they are mandated. The teacher either gives lectures or prepares stations for listening in the classroom. Tape records with five or six headsets can be provided in the classroom. The teacher can tape record his lecture outside of the class and then presents it as a learning alternative. The tape records of the lectures allows students to make up for the lesson later if they can't attend the class, the tape records even enables the lesson to go on when the teacher is absent. To support the auditory lecture with visual information, include pictures or visual elements in your lectures.

4. Design Hands-on Activities For All Subjects and Present Them: When the student intentionally and consciously perceive a concept, he stores it in his semantic memory, while storing the experiences in his episodic memory. 
5. Provide a Variety of Textbooks: It is a key step in moving away from a teachercentered classroom environment. Routin teaching from just one particular book is prevented. The fact that students can choose their own books from a wide range of source books allows to accomodate all reading levels. Many sources in other languages other than English are provided by many publishers. If students have many different books of their own, they have a chance to see how approaches and presentations of authors differ from each other. Thus, students begin to consider the books as instruments that support their learning. This forces teachers to bring various instructional materials to the classroom that will address students' needs.

6. Draw Students Into The Complexity of Thinking: The activities provided in the layers within the scope of the layered curriculum encourage students to think in more complex way in order to complete these activities. The tasks in $\mathrm{C}$ Layer require understanding of the basic concepts. The tasks in B Layer, however, call for manipulation or application of these concepts. The tasks in A Layer enables students to think critically on the subject.

\section{How to Evaluate Student-centered Activities in the Layered Curriculum}

According to Nunley (2003b, p. 35) the emphasis in the layered curriculum is on the actual learning rather than students' fulfillment of the task they have chosen. One of the best evaluation tools for student-centered activities is the rubric. It is recommended to distribute the rubric to sudents before the activities so that they can have an idea about the tasks and expectations required.

Along with rubric, students' oral defenses of the assignments -both before and after the task- can be used as a means of evaluation. Giving learners the opportunity to express heir opinions and defend themselves, oral defenses also enables the teacher to discover students' learning preferences and their lack of learning, and to what extend the learning has been fulfilled. Oral defenses are important in that they reduce the anxiety the students may feel during a test or written exam (Basbay, 2015, p. 259).

\section{Benefits Of The Layered Curriculum}

The the advantages that the layered curriculum provides can be summarized as follows (Nunley, 2017):

1. It individualizes the lesson.

2. As our expectations towards students naturally differ, it promotes alternative assessment and evaluation choices even when the students choose the same tasks.

3. It creates an opportunity to take oral defenses, make explanation and give extrainformation.

4. It decreases students' complaints about the assignments because they take their own learning responsibilities.

5. It reduces common behavioural problems in the class.

Despite all these advantages, there can be a few cons. As the layered curriculum encourages student-centered classrooms, at the beginning the students-not used to this type of clssroom- may misuse the freedom given within the framework of the studentcenteredness. Thus, some behaviorial problems may occur at the outset (Nunley, 2017). 
Also, they may feel some anger and anxiety in oral defenses (Nunley, 2003b, p. 34). To overcome these deficits, the instructor could clearly tell them that they should learn from the materials they prepare.

In the layered curriculum, based on Bloom's Taxonomy, the key concepts are given at the outset. More difficult and complex tasks are provided in the subsequent layers. In other words, the process is on an easy to difficult and simple to complex basis. (Basbay, 2006, p. 14; Yilmaz, 2010, p. 38). In the layered curriculum, with C, B, and A layers, various activities are presented to the students and they are based on selectivity principle. As the learner chooses among these activities with his free will, he also undertakes his own learning responsibility (Basbay, 2015, pp. 255-256). So it is true that the layered curriculum has motivating and encouraging aspects. Thus, the layered curriculum applications in English lessons can be said to ensure the motivating/encouraging and enjoyable learning environment indicated in the 2014 English Curriculum for Secondary Education by the Ministry of National Education.

\section{An Overwiev on the Current Language Teaching in Turkey}

The new educational model 4+4+4 mandates English language teaching be carried out from $2^{\text {nd }}$ grade of the primary school onward. According to the new curriculum, the weekly hours of English lesson in terms of grade level and school type are as follows:

From $2^{\text {nd }}$ grade to $4^{\text {th }}$ grade at primary school, English lessons are 2 hours a week. However, at the secondary school from $5^{\text {th }}$ grade to $8^{\text {th }}$ grade, English lessons are 4 hours in a week. As for the high schools, the weekly hours change slightly according to the school type. At Anatolian high schools, there are 4 hours in week from $9^{\text {th }}$ grade to $12^{\text {th }}$ grade. On the other hand, at the Fine Arts and Sports high schools, the weekly English lessons are 2 hours at all grades. Lastly, at Vocational and Technical high schools, the English lesson is 5 hours a week at the $9^{\text {th }}$ grade while it is 2 hours a week at the remaining grades.

Furthermore, with the 2017-2018 academic year, the foreign language intensive classes started at the $5^{\text {th }}$ grade at the secondary school as a pilot study in some schools throughout Turkey. The new amendments requires 18 hours English instruction a week (MONE, 2018).

\section{Research Objective and Importance}

In the English Curriculum for Secondary Education prepared by the Board of Education and Discipline of the Ministry of the National Education (2014), the pupose of the 9 grade English lesson equivalent to A1 and A2 levels in Common European Framework Text is to communicatively present the four skills of the language by integrating them. The attention is drawn to the importance of students' use of the materials that they themselves have prepared and having a deciding role in their own learning. Bearing in mind all these aspects, applying the layered curriculum in English lesson, giving students the chance to undertake their learning responsiblity and make selection among alternatives will support students' learning, enrich the routinized learning environment, and develop the four, generally overlooked skills (listening, speaking, writing and reading) in language teaching by allowing students to be active in learning environment. 
Examing the literature, it can be concluded that most of the studies on the layered curriculum are in such lessons as science (Demirel et al., 2006; Noe, 2008; Aydogus, 2009; Yilmaz, 2010; Bicer, 2011; Durusoy, 2012; Koc, 2013; Koc Akran and Uzum, 2018; Koc Akran, 2018; Yildiz, 2018; Onel and Dasci, 2018), social science (Basbay, 2006; Maurer, 2009; Gun, 2012; Oner, 2012) and mathematics (Johnson, 2007; Yildirim, 2016; Duman and Ozcelik, 2017; Yildirim Yakar and Albayrak, 2018). The other studies in terms of fields are as follows: Computer lesson (Zeybek, 2016), Sociology (Oner, et al., 2014), History (Ritter, 2008), Environmental Sciences (LaSovage, 2006), pre-service teachers (Gencel and Saracaloglu, 2018). On the other hand, in their studies Caughie (2016) and Childs (2003 as cited by Basbay, 2006) apply the layered curriculum by integrating it to the school curriculum. However, it is investigated that the applications of the layered curriculum in English lesson (Colding, 2008; Field, Himsl, Arsenault, Bedard and Singh, 2010;) are just part of the lesson activities in the lesson rather than scientific studies.

As a result of literature review, no layered curriculum applications in the field of English language instruction in Turkey have been detected. Considering all the points mentioned up to now and inadequacy of studies related to the layered curriculum in language teaching, it is thought that its effect as an alternative approach in language teaching should be examined and the study carried out would contribute the field with the data, documents and findings because the layered curriculum gives the students the opportunity to take responsibility of their own learning and to choose from the activities offered.

\section{METHOD}

\section{Research Design}

Consisting of an experimental group and control group, pre-test-post-test paired quasiexperimental design with control group was used in the study. According to Ozmen (2016, p. 57), the participants in this design are impartially distributed to the groups. Pre-tests and post-test are conducted both to the experimental group and control group pre and post the applications. During the experimental procedure, there is no interference in the control group whereas a special intervention is provided for the experimental group.

The experimental and control group used in the study is presented in Table 1.

Table 1

Appearance of the Experimental and Control Groups

\begin{tabular}{lllll}
\hline Groups & Forming Groups & Pretest & Experimental Process & Posttest \\
\hline E & $\mathrm{R}$ & $\mathrm{M}_{1,1}$ & $\mathrm{X}$ & $\mathrm{M}_{2,1}$ \\
$\mathrm{C}$ & $\mathrm{R}$ & $\mathrm{M}_{1,2}$ & & $\mathrm{M}_{2,2}$ \\
\hline
\end{tabular}

Retrived from: Ozmen, 2016, p. 57

E : Experimental Group

C : Control Group

R : Random

$\mathbf{X}$ : Experimental Process

M : Measurement 


\section{Study Group}

The study group consists of 67 students, studying in the 9th grade at Atatürk Anatolian High School in Siirt province in 2016-2017 academic year. In this study, carried out to investigate the effect of the layered curriculum on the academic achievement of students in the 9th grade English lesson, "purposive sampling" was used in determining the experimental and control groups. In the purposive sampling method, there is a wide variety of information sources that allow for detailed research (Buyukozturk, et al., 2016, p. 90).

In addition, the purposive sampling allows to recognize and explain different phenomena and events in many cases (Yildirim and Simsek, 2016, p. 135). It was determined that there were 4 classes as the ninth grade in the school where the applications were carried out. Fall term grades of the English lesson of the students at these four classes and the branches of the teachers were taken into account in determining the experimental and control groups.

The grades of the classes were found to be close to each other, but the experimental process was held with the students in 9/C and 9/D during the 2016-2017 school year becasuse the branch of teachers teaching English in the classes 9/A and 9/B was German teacher and the teacher of 9/C and 9/D was actually English teacher. Class 9/C was attained as the experimental and class 9/D as the control group. The number of the students in the experimental group was 34 and 33 students in the control group. The information about the students of in the experimental group and the control group that constituted the study group is given in Table 2 .

Table 2

Descriptive Information of Experimental and Control Group Students

\begin{tabular}{|c|c|c|c|c|c|c|}
\hline \multirow[b]{3}{*}{ Groups } & \multicolumn{4}{|c|}{ Gender } & & \\
\hline & Female & & Mal & & To & \\
\hline & (f) & $(\%)$ & (f) & $(\%)$ & (f) & $(\%)$ \\
\hline Experimental & 16 & 47,1 & 18 & 52,9 & 34 & 100 \\
\hline Control & 18 & 54,5 & 15 & 45,5 & 33 & 100 \\
\hline
\end{tabular}

According to Table 2, it can be said that the number of the male and female students in the experimental group are close to each other. In other words, $47.1 \%$ of the students in the experimental group are female and $52.9 \%$ are male students. On the contrary, the opposite is true for the control group. It turns out that the proportion of girls in the control group is higher than that of male students.

\section{Equality of Groups}

To determine the equivalence of the experimental and control groups, the average of the students' grade point (See Table 3) in the first semester (fall semester) of the 2016-2017 academic year was taken into consideration. Besides, the data obtained from the academic achievement test (See Table 4) for English lesson applied to experimental and control groups was considered. 
Table 3

Fall Term Mean Of The Scores In English Lesson

\begin{tabular}{ll}
\hline Class & Class Mean \\
\hline 9/A & 85,10 \\
9/B & 75,73 \\
9/C & 76,40 \\
9/D & 78,98 \\
\hline
\end{tabular}

Examining Table 3, except Class $9 / \mathrm{A}$, it is seen that the $9^{\text {th }}$ grade students' grade average of English lesson of the fall term of 2016-2017 academic year in Atatürk Anatolian High School are very close to each other. It turns out that there is a difference of about 10 points between 9 / A class and the other classes.

Statistical data on the scores of the experimental and control group students taken from the pretest practice of "Academic Achievement Test for English Lesson" is given in Table 4.

Table 4

Mann Whitney U Test Scores of The Experimental and Control Group on Pre-test Academic Achievement Test for English Lesson

\begin{tabular}{lllllll}
\hline & & $\mathrm{N}$ & Mean Rank & Sum of Ranks & $\mathrm{U}$ & $\mathrm{P}$ \\
\hline \multirow{2}{*}{ Group } & Experimental & 34 & 36,79 & 1251,00 & \multirow{2}{*}{466,000} & \multirow{2}{*}{232} \\
& Control & 33 & 31,12 & 1027,00 & & \\
\hline
\end{tabular}

According to Table 4, it is found that there is no significant difference between the scores of the experimental and control group students in the pre-test academic achievement test for English lesson [U=466, p>0,05]. In light of these findings, it can be stated that the groups are close to each other in terms of level because there is no significant difference in success between the groups [p> .05].

The Procedure (Layered Curriculum Application)

This study was conducted within a period of 14 weeks in the spring term of the 20162017 academic year. No intervention was made to the class which was not included in the study group and the information about the application process of the 9 / C class selected as the study group is given in the table below.

Table 5

Layered Curriculum Application Procedure

\begin{tabular}{|c|c|c|}
\hline Week 1 & $\Phi$ & $\begin{array}{l}\text { I Interview with the teacher to carry out the applications } \\
\text { \& Determination of the study group } \\
\text { \& Determination of the application unit with the teacher }\end{array}$ \\
\hline Week 2, 3 and 4 & 4 & $\begin{array}{l}\text { \& Preparation of the Academic Achievement Test } \\
\text { \& Pilot application of the Academic Achievement Test } \\
\text { \& The analysis of the data obtained from pilot application }\end{array}$ \\
\hline Week 5,6 and 7 & 4 & $\begin{array}{l}\text { \& Preparation of the activities for the application unit } \\
\text { \& Discussion with the teacher about the prepared activities } \\
\text { \& Informing students about the study to be done }\end{array}$ \\
\hline Week 8 & 4 & \& Application of the Academic Achievement Test as pretest \\
\hline Week 9 and 10 & 4 & \& Application of the $C$ layer activities \\
\hline Week 11 and 12 & 4 & + Application of the B layer activities \\
\hline Week 13 & 4 & \& Application of the A layer activities \\
\hline Week 14 & 4 & $\&$ Application of the Academic Achievement Test as posttest \\
\hline
\end{tabular}


The lists of the activities to be carried out in C, B and A layers within the scope of the layered curriculum were distributed to the students and asked to select the ones they wanted to do. Right after the activity selection, implementation processes started. First of all, the students carried out 4-5 activities in the C layer, then they did 1 activity in B and A layer each. The application began with the $C$ layer activities and ended up with the ones in the A layer. The list of the activities provided within the scope of the present study and samples are presented in Appendix-1 and Appendix-2.

\section{Data Collection Tools}

Data collection tools which are thought to contribute to the research in prodiving more detailed information about the participants and the implementation process are listed below and shown in Figure 2 according to the order of use.

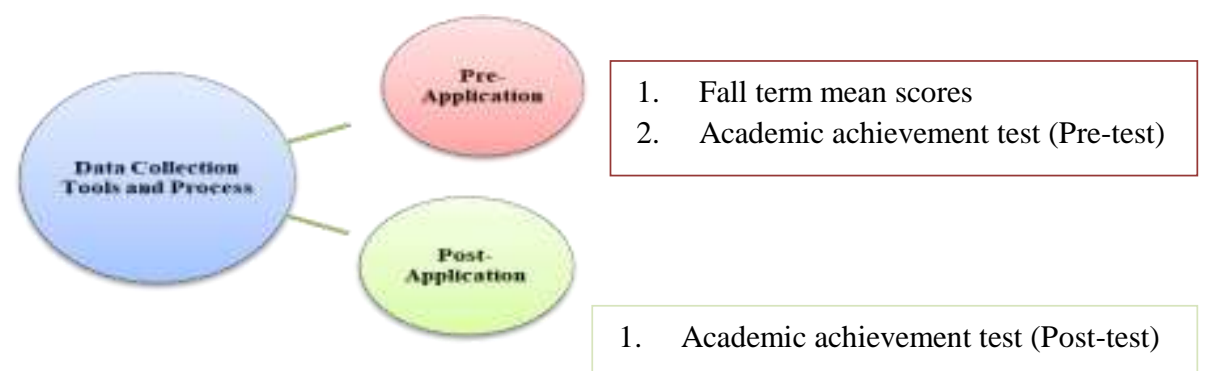

Figure 2

Data Collection Tools and Process Applied In the Research Design

According to Figure 2, the "Academic Achievement Test for English Lesson" developed by the researcher was implemented pre and post the application. The information on the academic achievement test used within the scope of the study is given below.

\section{Academic Achievement Test for English Lesson}

An achievement test was developed to determine the effect of the layered curriculum on the academic achievement of students in the 9th grade English lesson. During the development of the academic achievement test, Unit 7-Seven Wonders in the students' textbook on which the experimental applications was based and the educational attainments covered by this unit were taken into account. In the preparation of the questions for the achievement test, it was benefited from the acquisition understanding tests (https://odsgm.meb.gov.tr/) prepared by the General Directorate of Supporting and Training Courses (ODSGM) of the Ministry of National Education (MoNE), the 9th grade English textbook and the student workbook (Yildirim Publications) and various internet based sites. At the end of the studies, an academic achievement test with 40 questions was formed. The prepared academic test was presented to the views of 3 English teachers who taught this unit in the previous year, 1 Lecturer and 1 Instructor in the field of ELT. In the light of the evaluations and recommendations, a pilot application of the academic achievement test was conducted to achieve statistical processes such as 
item difficulty index, item discriminant power index, test reliability and mean difficulty. $10^{\text {th }}$ grade students who studied the same unit (Unit 7-Seven Wonders) in the previous academic year were determined for the pilot application. Based on volunteerism, the academic achievement test was applied to 671 students in the $10^{\text {th }}$ grade in the high schools in the city center of Siirt.

According to the analysis of the data obtained from the participants after the pilot application, the KR-20 reliability coefficient of the prepared academic achievement test was 0.90 and the mean of the test was 0.59 . To Ozcelik $(2010$, p. 184), the reliability should not be less than 0.80 in the tests used in education except for those with very few questions, and that the reliability should be 0.90 or higher in the tests where important decisions about the students are taken (as cited in Pesen, 2014, p. 77). Analysis of the test items are given in Table 5 .

Table 6

Item Analysis of the Academic Achievement Test for English Lesson

\begin{tabular}{llllll}
\hline Item No & Difficulty $(\mathrm{Pj})$ & Discrimination (rjx) & Item No & Difficulty $(\mathrm{Pj})$ & Discrimination (rjx) \\
\hline 1 & 0,24 & 0,25 & 21 & 0,20 & 0,24 \\
2 & 0,78 & 0,37 & 22 & 0,62 & 0,56 \\
3 & 0,19 & 0,13 & 23 & 0,21 & $-0,02$ \\
4 & 0,60 & 0,42 & 24 & 0,64 & 0,66 \\
5 & 0,65 & 0,45 & 25 & 0,87 & 0,37 \\
6 & 0,58 & 0,53 & 26 & 0,54 & 0,60 \\
7 & 0,63 & 0,54 & 27 & 0,37 & 0,44 \\
8 & 0,54 & 0,47 & 28 & 0,67 & 0,59 \\
9 & 0,47 & 0,49 & 29 & 0,71 & 0,61 \\
10 & 0,34 & 0,37 & 30 & 0,71 & 0,61 \\
11 & 0,41 & 0,37 & 31 & 0,66 & 0,67 \\
12 & 0,72 & 0,57 & 32 & 0,85 & 0,46 \\
13 & 0,59 & 0,52 & 33 & 0,77 & 0,57 \\
14 & 0,67 & 0,59 & 34 & 0,72 & 0,60 \\
15 & 0,49 & 0,53 & 35 & 0,85 & 0,45 \\
16 & 0,64 & 0,65 & 36 & 0,64 & 0,55 \\
17 & 0,65 & 0,54 & 37 & 0,69 & 0,57 \\
18 & 0,56 & 0,70 & 38 & 0,50 & 0,58 \\
19 & 0,57 & 0,57 & 39 & 0,68 & 0,57 \\
20 & 0,51 & 0,69 & 40 & 0,52 & 0,60 \\
$\mathrm{~N}=671$ & & & & & \\
\hline
\end{tabular}

When Table 6 is examined, it is seen that the item discrimination power of the questions 1, 3, 21 and 23 is low. As Tekin (1991, p. 249) stated, the following criteria must be considered in the analysis of test items;

- Items with a discrimination index of 0,40 or greater are very good items

- Items with a discrimination index of 0,30 and 0,39 are quite good, but be worked on to improve

- Items with a discrimination index of 0,20 and 0,29 are the ones to be corrected and improved

- Items with a discimination index of 0,19 or less are very weak and must be removed from the test if they can not be corrected and improved. 
The item discrimination power index of the questions was measured and two items (Item 3 and Item 23) whose item discrimintaion power index was below 0,19 were removed from the test. Of the two items (Item 1 and Item 21) whose item discrimination power index was between 0,20 and 0,29, Item 1 was removed from the test and Item 21 was reincluded in the test after being corrected because it was a question about reading comprehension text and part of a whole passage. The reliability analysis was conducted again after removing items 1,3 , and 23. As a result of the analysis, the reliability coefficient of the test -KR-20- was obtained as 0.89. After these procedures, 37 questions were included in the final form of the achievement test and were administered as pretest and posttest to experimental and control groups.

\section{Data Analysis}

In this study that was carried out to investigate the effect of the layered curriculum on the academic achievement of the sudents in 9th grade English lesson percent (\%) and frequency (f) were used for the personal information of the students in experimental and control groups. Data obtained from the "Academic Achievement Test for English Lesson" administered as pre and posttest to experimental and control groups were statistically analyzed in SPSS 21.0 package program. Data obtained from the "Academic Achievement Test for English Lesson" was first anlyzed for normal distribution. As the data was not normally distributed, non-parametric tests were used. To compare pretest and posttest academic achievement scores, Mann Whitney U test was used, and the Wilcoxon Marked Rank test was used to evaluate the experimental and control groups in themselves. The statistical analyzes were based on $\mathrm{p}<0.05$ significance level.

\section{FINDINGS}

The statistical data on the pretest and posttest "Academic Achievement Test for English Lesson" scores of the students in the experimental group is given in Table 7.

Table 7

Wilcoxon Signed Ranks Test Scores of the Experimental Group on Pre and Post-test Academic Achievement Test for English Lesson

\begin{tabular}{|c|c|c|c|c|c|c|}
\hline \multicolumn{2}{|c|}{ Variables } & $\mathrm{N}$ & Mean Rank & Sum of Ranks & $\mathrm{Z}$ & $\mathrm{P}$ \\
\hline & Negative Ranks & 4 & 6,50 & 26,00 & $-4,360$ & \\
\hline Experimental & Positive Ranks & 27 & 17,41 & 470,00 & &, $00^{*}$ \\
\hline Grou & Ties & 3 & & & & \\
\hline
\end{tabular}

Examining Table 7, it is seen that after undergoing the layered curriculum applications, the scores of the students in the experimental group are higher than the scores they get before being subjected to the layered curriculum applications. According to the results of the Wlcoxon Signed Rank test, conducted to find out whether there was any difference between scores that the experimental group students got on the pre and post academic achievement test for English lesson, there is a statistically significant difference between pre- and post- test scores of the experimental group students $[\mathrm{z}=-$ 4,360, $\mathrm{p}<0,05]$. 
These findings can be interpreted as the achievement levels of the students in the experimental group being positively affected academically from the application of the layered curriculum and the success levels being increased.

To discover whether there was a significant difference between pre and post test scores of the students in the control group, the results of the repeated measures on the same group were compared. The statistical data on the pretest and posttest "Academic Achievement Test for English Lesson" scores of the students in the control group is given in Table 8.

Table 8

Wilcoxon Signed Ranks Test Scores of the Control Group on Pre and Post-test Academic Achievement Test for English Lesson

\begin{tabular}{cllllcc}
\hline & Variables & N & Mean Rank & Sum of Ranks & Z & P \\
\hline \multirow{2}{*}{ Control } & Negative Ranks & 7 & 18,14 & 127,00 & & \\
Group & Positive Ranks & 26 & 16,69 & 434,00 & $-2,748$ & \multirow{2}{*}{$006^{*}$} \\
& Ties & 0 & & & & \\
\hline
\end{tabular}

According to Table 8, there was a statistically significant difference between the scores of pre and post application of the control group according to the result of Wilcoxon Signed Rank test, which was conducted to determine whether there was a difference between pre and post test academic achievement test for English lesson scores of control group students exposed to activities in their textbook $[\mathrm{z}=-2,748, \mathrm{p}<, 006]$. This may be due to the fact that competition in each area is present among students and that students may benefit from different sources such as private teaching institutions and tutoring.

The statistical data on the posttest "Academic Achievement Test for English Lesson" scores of the students in the experimental and control groups is given in Table 9.

Table 9

Mann Whitney U Test Scores of The Experimental and Control Group on Post-test Academic Achievement Test for English Lesson

\begin{tabular}{lllllll}
\hline \multirow{2}{*}{ Group } & & $\mathrm{N}$ & Mean Rank & Sum of Ranks & U & P \\
& Experimental & 34 & 40,06 & 1362,00 & \multirow{2}{*}{355,00} & \multirow{2}{*}{$010^{*}$} \\
& Control & 33 & 27,76 & 916,00 & & \\
\hline
\end{tabular}

As shown in Table 9, there was a significant difference between the posttest scores of the experimental and control group students in academic achievement test for English lesson $[\mathrm{U}=355, \mathrm{p}<, 010]$. Bearing in mind the mean rank, there was a difference of approximately 18 points between the students in the experimental group ( $\bar{X}=40,06$ ) and the control group ( $\bar{X}=27,76$ ). This result can be interpreted as that the layered curriculum is more effective in enhancing student achievement than the activities in the student textbook.

\section{DISCUSSION AND CONCLUSION}

At the end of present study held to investigate the effect of the layered curriculum on academic achievement in English lesson, a significant difference between pretest and 
posttest academic achievement scores of the experimental group was observed. Considering this result, it can be said that layered curriculum applications positively affected academic achievement of students and increased their success level. According to Bicer (2011), this increase is due to the fact that the mental process of the students exposed to layered curriculum is always operating because in the layered curriculum students always makes researches to reach information. At the end of these researches students arrange previous information and the new one, and resort to this new information in problem solving. Thus, it can be said that "the mental process of the students exposed to layered curriculum is always active" (Koc, 2013, p. 175). Moreover, "owing to such characteristics as presenting assignment options to the learners, encouraging the learners to make research, providing them with alternative options according to their individual features and allowing them to be active in the learning environment, students are motivated and thus their success increased" (Bicer, 2011, p. 86). In his study conducted to find out whether the lesson differentiated with layered curriculum would increase the success of high school students, Ritter (2008) determined that there was an increase in grades of the students in category A with a rate of $9,7 \%$, and an increase in the number of students between category $\mathrm{C}$ and $\mathrm{D}$. He also observed a $1,8 \%$ decrease in the number of the students who failed the courses. This can be said to demonstrate that with the layered curriculum applications students' academic achievement increased. Looking at the high difference between the pre and post pest scores of the experimental group in the present study, the findings parallel with those in Ritter's study. In their study titled "Layered Curriculum In The 9th Grade Applied Egnlish Lesson", Field, et al. (2010) explored that layered curriculum increase students' success, and an approximately $19,1 \%$ of the students who could not get any points in 2008-2009 academic year decreased to a rate of $13,6 \%$ with the applications. Colding (2008) applied layered curriculum in 12th grade English lesson while teaching a poem named Beowulf, and observed that after perceiving the basic concepts, students focused on the more challenging and and difficult activities and assignments using their critical and analytical thinking skills. In her study titled "Effects of a Layered Curriculum Format of Instruction in a High School Environmental Science Energy Unit", LaSovage (2006) determined that layered curriculum was effective on students' success and retention, and observed progress in the attitudes of students towards the lesson. Herein, it can be stated that giving students a chance to choose among the assigments facilitates academic output as the students are positively motivated by having accountability and the learning environment enriched. All these findings back up the the results of the present study The control group students were motivated and encouraged by doing hands-on activities and actively participating in the lesson, so they acquired the topics lastingly. Thus, the process was academically fruitful fro them. The studies by Ferrier (2007), Kadum-Bošnjak and Buršić-Križanac (2012), Mbugua and Muthomi (2014), Valiandes (2015), Leonardo, et al. (2015), Abbas and Abdurrahman (2015) and Bal (2016) can be said to support the arguments under discussion in the present study. The researchers discovered in their studies that the differentiated and learner-centered environment improved students' achievement significantly. 
When the literature is examined, it is seen that the findings of various studies are in line with those obtained from the present study. In her study carried out to discover the effect of the layered curriculum and creative drama on students' achievement and retention, as the result of the test applied to the experimental group, Durusoy (2012, p. 60) determined that after being exposed to the layered curriculum students' scores increased and that the layered curriculum enhanced students' success level. Likewise, Koc (2013, p. 171) and Gun (2012, p. 63) conducted pretest and posttest to the students underwent the layered curriculum applications. The researchers had a significant difference between the pretest and posttest scores of the students at the end of the t-test which they applied to the pretest and posttest scores of the experimental group and they concluded that the layered curriculum was effective in increasing students' achievement. In the study "The Effect of Layered Curriculum Use for the 7th Grade Circle and Circular Region Subject on Academic Success and Attitude towards Mathematics" by Duman and Ozcelik (2017, p. 1298), a significant difference between pretest and postest academic achievement scores of the experimental group students was discovered. Starting from this result, the researchers concluded that layered curriculum was effective in increasing students' success in maths.

Considering the individual characteristics of all individuals in the learning environment, the layered curriculum in the present study increased the success of learners by offering a variety of activities to address different intelligences, learning styles, and needs. In other words, through providing learners with multiple learning tasks and freeing the learning environment from monotony the layered curriculum was instrumental in bringing the achievements of students to higher levels. When the literature is examined, it is seen that the findings of various studies which show that the differentiated learning environments used in language teaching increase the academic achievement of the students are supporting the findings obtained in the present study. For example, in Bozkurt's (2014, p. 69) study "Effect of Blended Learning Environments Developed for Students in English Courses on Perceived Academic Achievement and Self-efficacy", it is seen that the average of the experimental group on pretest conducted before the application was 56,88 and the average of the group was 69,34 after the application. Thus, it can be concluded that enriching and differentiating learning environment in English lesson contribute to the academic performance. At this point, the study by Alonge, et al. (2017) can be said to back up this conclusion. The researchers found out that performance of the students taught using differentiated instruction was wonderful ESL achievement test. The findings of the study by Aliakbari and Khales Haghighi (2014) are also in line with this conclusion. They observed that differentiated instruction fostered reading comprehension of the students in elementary and intermediate classrooms.

As a result of the research, a statistically significant difference was also found when the academic achievement pre-test and post-test scores of the control group students were compared. This is an expected result. The reason is that the right strategies, methods and techniques are used in order to obtain the educational attainments required by the curriculum while English is being taught. Therefore, the control group achieved a better academic status than its existing situation. However, a statistically significant difference 
was found in favor of the experimental group when the posttest scores of the experimental and control groups were compared in order to determine whether the experimental application was more effective than the current practice. This result can be interpreted as the fact that the lessons taught through layered curriculum applications were more effective than the activities in the current curriculum. Considering the fact that each individual has different learning styles and paying attention to indiviual characteristics of each individual can be counted among the reasons for this result. As a matter of fact, Bas (2014, p. 190) stated that students learned more effectively in their own way of learning in English language teaching and all of this contributes positively to academic achievement. When the literature is examined, there are studies in line with the result obtained in the present study. In her study in which she applied the layered curriculum, Zeybek (2016) identified a significant difference between the level of understanding of the experimental and control group students and the total access points in favor of the experimental group. She also found a significant difference between the retention averages of the experimental group students and the average retention points of the control group students. Likewise, Oner (2012) investigated that students, subjected to layered curriculum supported by multiple intelligence, were more successful than students exposed to traditional teaching and that the attittudes of the students in the experimental group were positively affected. Bicer (2011) also put forward in her study that the experimental group students' achievement level and their score averages of the pre and post attitude towards the lesson were higher than the control group students'. Aydogus (2009) stated that the academic achievement was higher in the three experimental groups that were subjected to the layered curriculum than the group that is taught by the traditional method. In the study conducted to explore the effect of the layered curriculum and the traditional teaching, Noe (2008) found out that the layered curriculum was more effective in enhancing academic achievement compared to the traditional teaching. However, there are studies that do not match the results of this study. For example, in the study titled " The Evaluation of Layered Curriculum In terms of Process and Product" by Demirel, et al. (2006) it is seen that there was no significant difference between achievement test results and attitude scores of experimental group students and control group students.

In the present study, the students were active throughout the experimental process. They were given the opportunity to bear the responsibility of their own learning. They took great pleasure while doing the activies provided according to their learning styles. Thus, the process was fertile and boosted their learning and achievement.

As a result of the research, the following suggestions have been developed:

1- The use of new approaches such as the layered curriculum which gives students an opportunity to select by taking into account individual characteristics like intelligence, learning styles and encourages them to take responsibility for their own learning as well as promoting an entertaining learning environment by freeing it from monotony will be beneficial. 
2- While preparing tasks for $\mathrm{C}, \mathrm{B}$ and $\mathrm{A}$ layers within the scope of the layered curriculum, more emphasis can be put on reading, writing, speaking and listening to improve communication skills.

3- Reviewing the literature, it is seen that the layered curriculum applications are only limited to scientific studies in our country. To make it widespread, teachers can offer students the option of layered curriculum-based activities through the websites of their schools or through their personal blogs.

In the present study, the three layers were used together. In the future studies, each layer can be used seperately and their effect can be studied alone.

\section{REFERENCES}

Abbas, G.A., \& Abdurrahman, M.S. (2015). The Effectiveness of Differentiated Instruction on Students' Geometric Achievement in Kebbi State Senior Secondary Schools, Nigeria. International Journal of Scientific \& Engineering Research, 6(1). 1905-1922. Paper ID - 1059351, ISSN 2229-5518

Aliakbari, M., \& Khales Haghighi, J. (2014). Impact of Differentiated Instruction Strategies and Traditional-Based Instruction on the Reading Comprehension of Iranian EFL Students. Research in Applied Linguistics, 5(1), 109-129.

Alonge, S., Obadare, F. T., \& Obateru, O. T. (2017). Effect of Differentiated Phonics Instructional Strategy on Primary School Pupil's Learning Outcomes in English Literacy Skills in Ikere-Ekiti. KIU Journal of Humanities, 2(1), 339-343.

Aydoğuş, R. (2009). Ilköğretim 6. ve 7. sinıf fen ve teknoloji dersinde basamakl ögretim yönteminin akademik başartya etkisi. (Master Thesis), Sosyal Bilimler Enstitüsü, Afyonkarahisar.

Bal, A. P. (2016). The Effect of the Differentiated Teaching Approach in the Algebraic 1

Learning Field on Students' Academic Achievements. Eurasian Journal of Educational Research, 16(63). 185-204. http://dx.doi.org/10.14689/ejer.2016.63.11

Baş, G. (2014). İngilizce Dersinde Çoklu Zekâ Yaklaşımı Temelli Öğretimin Öğrenci Görüşleri Açısından Değerlendirilmesi. Kastamonu Eğitim Dergisi, 22(1). http://79.123.169.199/ojs/index.php/Kefdergi/article/view/84/81

Başbay, A. (2006). Basamakl öğretim programıyla desteklenmiş proje tabanl ögrenmenin sürece, ögrrenen ve ögrretmen görüsllerine etkisi. (Doctoral Dissertation), Hacettepe üniversitesi, Ankara.

Başbay, A. (2015). Basamakı Öğretim Programı. Özcan Demirel (Ed.), Eğitimde Yeni Yönelimler (ss. 251-270) (6. bs.), Ankara: Pegem Akademi Yayıncılık.

Biçer, S. (2011). Fen ve teknoloji dersinde basamakll öğretim yönteminin ögrrenci başarısına, kalıcllı̆g ve tutumlarına etkisi. (Master Thesis), Firat üniversitesi, Elazığ. 
Bozkurt, Ö.F. (2014). Ingilizce kurslarındaki öğrenciler için geliştirilen harmanlanmış ögrenme ortamlarının akademik başarı ve öz-yeterlik algısına etkisi. (Master Thesis), Gazi üniversitesi, Ankara.

Büyüköztürk, Ş., vd. (2016). Bilimsel Araştırma Yöntemleri. (20. bs.). Ankara: Pegem Akademi Yayıncılık.

Cibişoğlu, M.A. (2016). Öğrencilerin toplumsal kökenlerinin, yabancı dil başarılarına ve yabancl dil ögrenmeye yönelik tutumlarına etkisi. (Master Thesis), Ankara Üniversitesi Eğitim Bilimleri Enstitüsü, Ankara.

Caughie, B.D. (2016). The perceived impact of the layered curriculum instructional model on student engagement. Holy Family University, Doctorate in Education (EdD). ProQuest LLC UMI Microform 10011442.

Colding, H.D. (2008) Integrating A Layered Curriculum To Facilitate Differentiated Instruction (http://www.ascd.org/ascd-express/vol3/324-colding.aspx adresinden erişildi.

Demirel, Ö., Şahan, H. H., Ekinci, N., Özbay, A., \& Begimgil, M. (2006). Basamaklı Öğretim Programının Süreç ve Ürün Açısından Değerlendirilmesi. Milli Eğitim Dergisi, 172, 72-90.

Duman, B. ve Özçelik, C. (2017). 7. Sınıf Çember ve Daire Konusunda Basamaklı Öğretim Uygulamasının Öğrencilerin Matematik Dersine İlişkin Akademik Başarı ve Tutumlarına Etkisi. Bartın Üniversitesi Eğitim Bilimleri Dergisi 6(3). 1293-1308. doi: 10.14686/buefad.339559.

Durusoy, H. (2012). 6.sınıf kuvvet ve hareket ünitelerinde basamaklı ögretim yöntemi ve yaratıcı drama yöntemlerinin ögrenci erişine ve kalıcllı̆̆a etkisi. (Master Thesis), Hacettepe üniversitesi, Ankara.

EF EPI 2018. EF English Proficiency Index 2018 Report. Retrieved November, 26, 2018 From https://www.ef.com.tr/epi

Ferrier, A. M. (2007). The effects of differentiated instruction on academic achievement in a second-grade science classroom[Abstract](Doctoral dissertation, Walden University).

Field, K., Himsl, J., Arsenault, L., Bedard, T., ve Singh, S. (2010). Layered curriculum in the grade nine applied classroom. http://misabarrie.curriculum.org/storage/281/files2/AjaxCurriculumGrade9.pdf

Gencel, I. E., \& Saracaloglu, A. S. (2018). The Effect of Layered Curriculum on Reflective Thinking and on Self-Directed Learning Readiness of Prospective Teachers. International Journal of Progressive Education,14(1), 8-20. doi: 10.29329/ijpe.2018.129.2 
Gün, E.S. (2012). Çoklu zekâ kuramı ile desteklenmiş olan basamaklı öğretim programinin öğrenci erişine, kalıcllı̆̆a ve ögrenme süreçlerine etkisi. (Doctoral Dissertation). Hacettepe üniversitesi, Ankara.

https://odsgm.meb.gov.tr/kurslar/KazanimTestleri

http://www.okunur.net/dunyada-konusulan-diller/ Reached: 05.01.2017

Johnson, K. J. (2007). Layered curriculum for the construction trades: a mathematics curriculum to teach trade students basic math skills to be successful apprentices. Carbondale: Southern Illinois University.

Kadum-Bošnjak, S., \& Buršić-Križanac, B. (2012). Impact Of Differentıated Instruction On Achievement In Teaching Mathematics To Lower-Stage Grades. Methodological Horizons, 7(15), 15-29.

Koç, S. (2013). Basamakl ögretim programı uygulamasinın 6.sınıf fen ve teknoloji dersinde ögrencilerin biliş ötesi farkindalıkları ve problem çözme becerilerine etkisi. (Doctoral Dissertation), İnönü üniversitesi, Malatya.

Koc Akran, S., \& Uzum, B. (2018). The effect of the Layered Curriculum on the 6th Grade Students' Learning Styles in Science Lesson. International Journal of Educational Methodology, 4(3), 141-152. doi: 10.12973/ijem.4.3.141

Koc Akran, S.(2018). The Effect of the Application of the Layered Curriculum on the Metacognitive Awareness of Students in the 6th Class Science and Technology Lesson. E-AJELI (Anatolian Journal of Educational Leadership and Instruction), 6(1), 1-25. http://dergipark.gov.tr/ajeli/issue/38074/368704

LaSovage, A.J. (2006). Effects of using layered curriculum fromat of instruction in high school environmental science energy unit. Michigian State University. ISBN 0542896745,9780542896743 .

Leonardo, R. R., Nivera, G. C., \& Reyes, A. S. (2015). Effects of Differentiated Instruction on College students' Achievement in and Attitude towards Trigonometry. The Normal Lights, 9(1). 119-133

Maurer, L., A. (2009). Evaluating the use of layered curriculum and technology to increase comprehension and motivation in a middle school classroom. Michigan State University, Master of Science. Interdepartmental Physical Sciences. ProQuest LLC UMI Microform 1471872.

Mbugua, Z. K., \& Muthomi, M. W. (2014). Effectiveness of Differentiated Instruction on Secondary School Students Achievement in Mathematics. International Journal of Applied Science and Technology. 4(1). 116-122.

Ministry of National Education (MONE) (2018). Ortaöğretim Kurumları Haftalık Ders Çizelgeleri-2018.Retrieved

https://ttkb.meb.gov.tr/meb_iys_dosyalar/../21173451_ort_ogrtm_hdc_2018.pdf 
Noe, B. (2008). The effects of a layered curriculum versus traditional teaching methods on academic achievement of fourth graders in the science content area. Unpublished Master Thesis, Degree of Master of Education in Divergent Learning in the Graduate School, Colombia College.

Nunley, K.F. (2016). Six simple steps to layered curriculum. Retrieved from http:// www.help4teachers.com/five.htm on 21.12.2016.

Nunley, K.F. (2003b). How to grade student-centered assignments while maintaining high standards. Retrieved from http://help4teachers.com/grading.htm on 25.12.2016.

Nunley, K.F. (2017). Advantages to layered curriculum. Retrieved from http://www.help4teachers.com/whyy.htm on 05.01.2017

Nunley, K.F. (2003a). Giving Credit Where Credit is Due. Principal Leadership, 3(9), 26-30. http://www.iaae.net/files/studentcenteredlearningaccountability.pdf

Nunley, K.F. (2003b). Layered Curriculum Brings Teachers to Tiers. Education Digest, 69(1), http://www.wp.cune.org./Jordanstirzt/files/2014/03/10736373.pdf

Önel, A. ve Derya Daşcı, A. (2018). Fen Bilimleri Öğretmen Adaylarının Basamaklı Öğretim Programı Uygulamasına İlişskin Görüşleri [Views of science teacher candidates related to layered education curriculum]. Erzincan Üniversitesi Eğitim Fakültesi Dergisi, 20 (2), 517-535. doi: 10.17556/erziefd.413492

Öner, G., Ünsal, S., Meşe, N. N., \& Korkmaz, F. (2014). Orta öğretim Sosyoloji Dersinde Örnek bir Basamaklı Öğretim Uygulaması. University of Gaziantep Journal of Social Sciences, 13(1), 229-243. http://eds.b.ebscohost.com/eds/pdfviewer/pdfviewer?vid=1\&sid=b99dae76-f8ce-44d9ba9f-0d7b4ced6d3d\%40sessionmgr104

Öner, Ü. (2012). Sosyal bilgiler dersinde çoklu zekâ destekli basamaklı ögretim programının, öğrencilerin akademik başarısına, tutumlarına ve kalıcılığa etkisi. (Doctoral Dissertation). Atatürk üniversitesi, Erzurum.

Özkan, E.S., Karataş, İ.H., ve Gülşen, C. (2016). Türkiye'de 2003-2013 Yılları Arasında Uygulanan Yabancı Dil Eğitimi Politikalarının Analizi. Eğitim ve Öğretim araştırmaları Dergisi, 5(1), 245-254.

Özmen, H. (2016). Kuramdan Uygulamaya Eğitimde Bilimsel Araştırma Yöntemleri. Mustafa Metin (Ed.) (3. bs.), Deneysel Araştırma Yöntemi (ss.47-76) içinde. Ankara: Pegem Akademi Yayıncılık.

Pesen, A. (2014). Harmanlanmış ögrenme ortamının öğretmen adaylarının akademik başarısına, ders çalışma alışkanlıklarına ve güdülenme düzeylerine etkisi. (Doctoral Dissertation), Dicle üniversitesi, Diyarbakır.

Ritter, S. (2008). Effects of layered curriculum in a high school. https://msagostino.files.wordpress.com/.../differentiated_inst... doc. 28.12.2016 
Salman, R.M. (2011). Ağrl ilindeki lise öğrencilerinin yabancı dil olarak İngilizceye yönelik tutumları. (Master Thesis). Kars: Sosyal Bilimler Enstitüsü.

Talim Terbiye Kurulu Başkanlığı- Board of Education and Discipline- (TTKB), (2014). Ortaöğretim İngilizce Dersi (9,10,11 ve 12. Sinıflar) Öğretim Programı. 22.12.2016, http://ttkb.meb.gov.tr/program2.aspx

Tekin, H. (1991). Eğitimde Ölçme ve Değerlendirme. Ankara: Yargı Kitap ve Yayınevi.

Valiandes, S. (2015). Evaluating the Impact of Differentiated Instruction on Literacy and Reading in Mixed Ability Classrooms: Quality and equity dimensions of education effectiveness. Studies in Educational Evaluation, 45, 17-26.

Yıldırım Yakar, Z., \& Albayrak, M. (2018). Alan ölçmenin basamaklı öğretim yöntemiyle öğretiminin öğrenci başarısına etkisi [The Effect of the Layered Curriculum Method on the Students' Achievement in "Area Measurement"]. Hacettepe Üniversitesi Eğitim Fakültesi Dergisi. Advance online publication. doi: 10.16986/HUJE.2018044393

Yıldırım, Z. (2016). "Alan ölçme” öğretiminde basamakl öğretim yönteminin etkisinin incelenmesi. [Abst]. Doctoral Dissertation, Atatürk üniversitesi, Erzurum. https://tez.yok.gov.tr/UlusalTezMerkezi/tezSorguSonucYeni.jsp

Yıldırım, A. ve Şimşek, H. (2016). Sosyal Bilimlerde Nitel Araştırma Yöntemleri (Genişletilmiş 9.bs.). Ankara: Seçkin Yayınları.

Yıldız, M. (2018). Ilkokul 4. Sinıf Fen Bilimleri Dersinde Yansittcı Öğretim İle Desteklenmiş Basamaklı Öğretimin Akademik Başarlya Ve Tutuma Etkisi [The Effect Of Layered Curriculum Supported By Reflective Teaching On Academic Achievement And Attitude Primary School 4th Grade Science Course]. (Master's thesis, Bartın Üniversitesi, Eğitim Bilimleri Enstitüsü).

Yılmaz, F. (2010). Fen ve teknoloji dersinde basamakl öğretim programı uygulamaları. (Doctoral Dissertation), Anadolu Üniversitesi, Eskişehir.

Zeybek, G. (2016). Basamaklı öğretim uygulamasının öğrenci erişsisi ve kalıcılı̆ga etkisi. [özet]. Doctoral Dissertation, Necmetin erbakan üniversitesi, Konya. https://tez.yok.gov.tr/UlusalTezMerkezi/tezSorguSonucYeni.jsp. 


\section{APPENDIX-1}

Lists of Activity Samples Presented Within the Scope of the Layered Curriculum

\section{LAYER C ACTIVITIES}

Dear Students,

Choose how many activities you wish, worth 70-75 point from the list below.

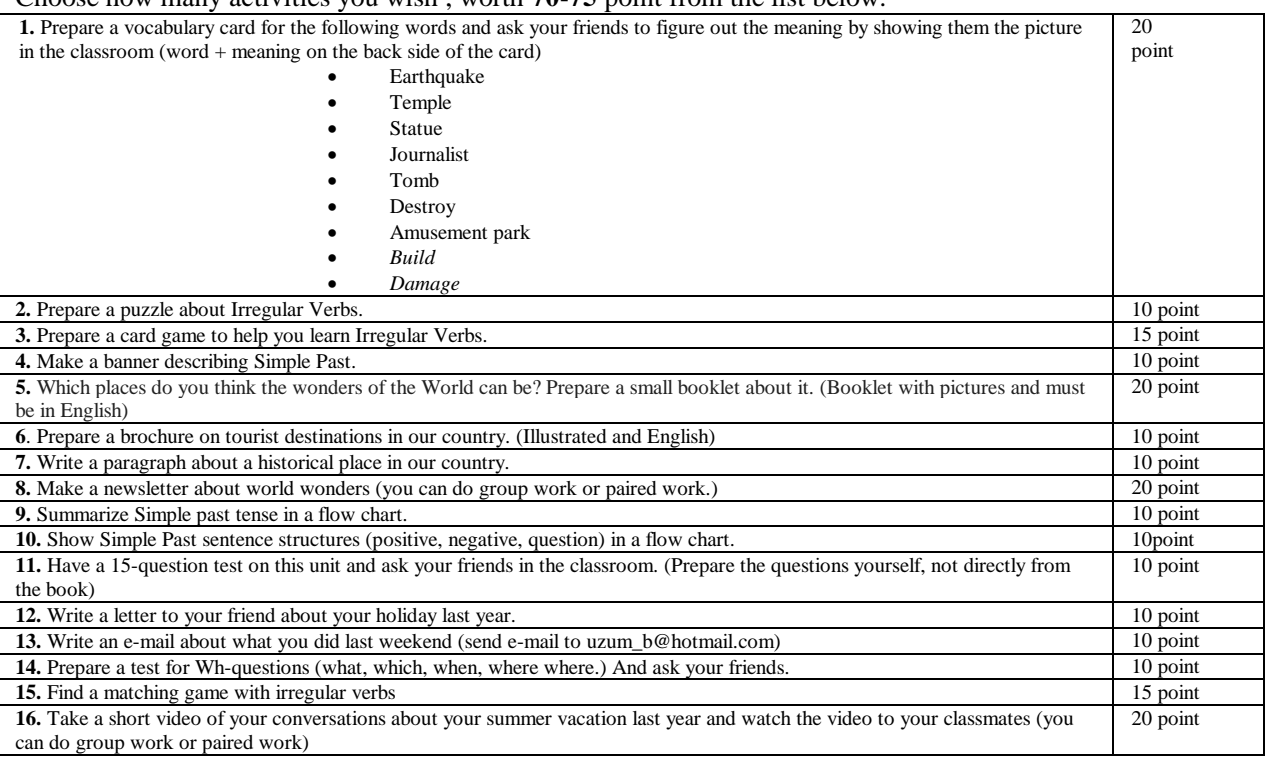

\section{LAYER B ACTIVITIES}

Dear Students,

Choose just one activity from the list below.

\begin{tabular}{|l|l}
\hline 1. Make an advertisement about the 7 wonders of the world. & 15 point
\end{tabular}

\begin{tabular}{|c|c} 
2. Prepare a powerpoint presentation about the 7 wonders of the world. & 15 point \\
\hline
\end{tabular}

3. Search from a variety of sources and edit the class board with the pictures / text and banners you found. (Group work can be 15 point

done.)

4. Make your own world wonder list and present it in the classroom.

5. Write an article about what you and your family did last summer. (simple past to be used).

\begin{tabular}{|l|l|}
\hline & 15 point \\
\hline & 15 point \\
\hline
\end{tabular}

\begin{tabular}{l|l}
\hline $\begin{array}{l}\text { 7. Do your research on the internet about your favorite singer / tv actor / actor / actress. Write at least } 10 \text { sentences describing } \\
\text { what he/she did last week. }\end{array}$ & 15 point \\
\hline
\end{tabular}

8. Keep a dairy. (Write what you did on that day using simple past - time)

9. Write a poem about Natural Beauties

10. Write a poem/ song using the Simple Past or Wh-question patterns:

\begin{tabular}{lll}
\hline & 15 point \\
\hline
\end{tabular}

11.Do the workseet

12.Do the worksheet
13. Choose one of the 7 wonders of the world and create a concept map about it.

LAYER A ACTIVITIES

Dear Students,

Choose just one activity from the list below.

1. Write a 150-word composition about the 7 wonders of the world

2. Have an interview with your teacher about what you did last suld

\begin{tabular}{|l|l}
\hline 3. Write a & 15 point \\
\hline 4. What & 15 pont
\end{tabular}

\begin{tabular}{|l|l} 
4. What is the Wonder of your Dream World? Make a model of it and present it in class. & 15 point
\end{tabular}

5. Prepare short TV ad about places to visit in your city/ country.

6. Make a postcard about your dream World of Wonders. The front side of the postcard must have a picture and some brief

information about it.

International Journal of Instruction, January2019 • Vol.12, No.1 


\section{APPENDIX-2}
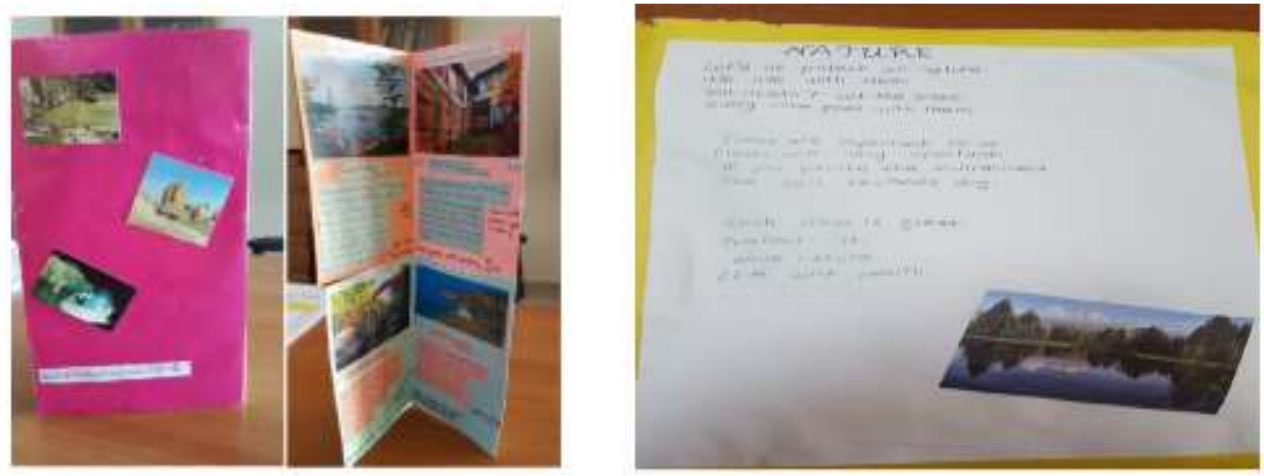

A brochure on tourist destinations. (Illustrated and English) (C Layer)

A Poem about Natural Beauty (Layer B)

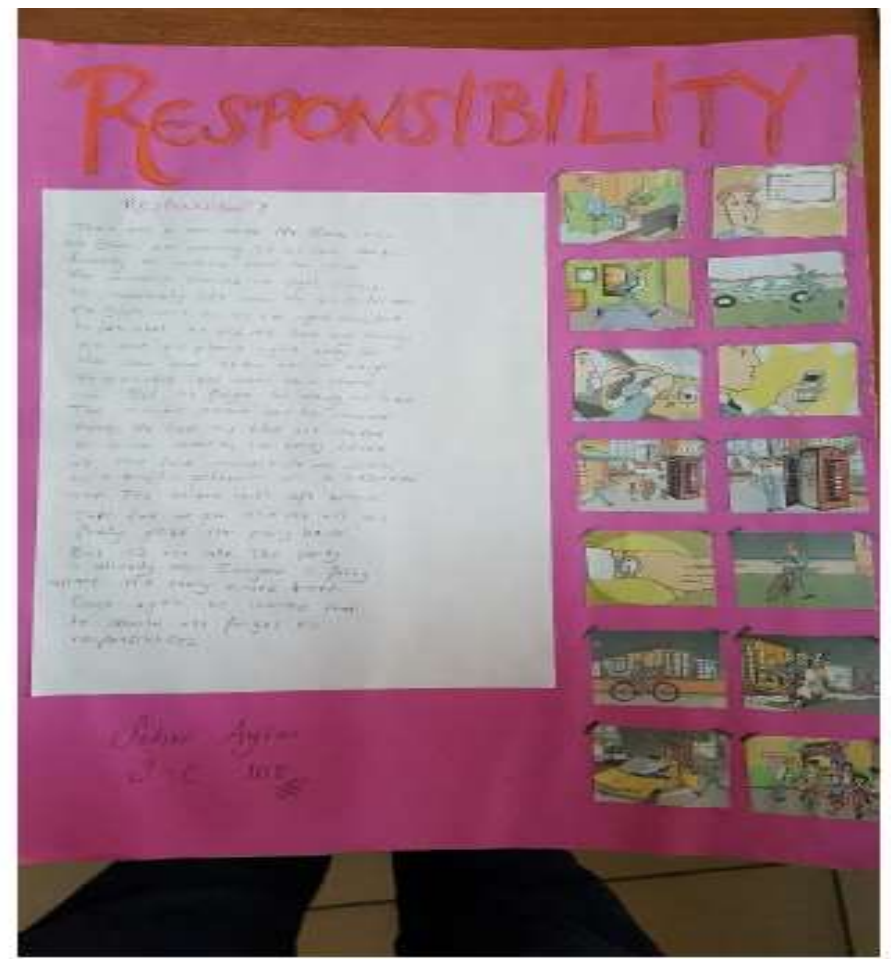

The Picture Story (Layer A) 